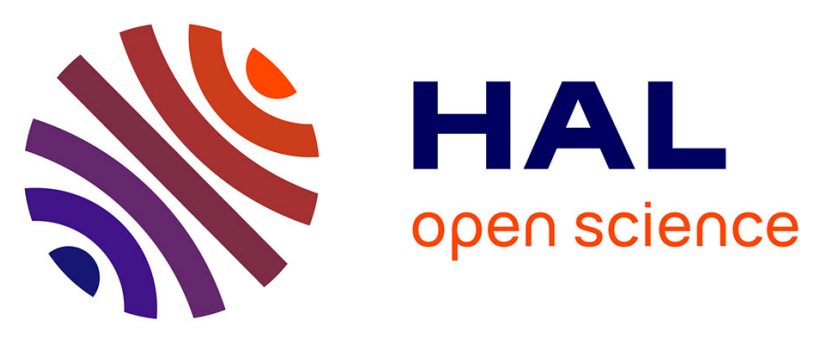

\title{
Consecutive food and respiratory allergies amplify systemic and gut but not lung outcomes in mouse
}

Gregory Bouchaud, Pascal Gourbeyre, T. Bihouée-Roussey, P. Aubert, D.

Lair, M.-A. Cheminant, Sandra S. Denery-Papini, M. Neunlist, A. Magnan, Marie Bodinier

\section{To cite this version:}

Gregory Bouchaud, Pascal Gourbeyre, T. Bihouée-Roussey, P. Aubert, D. Lair, et al.. Consecutive food and respiratory allergies amplify systemic and gut but not lung outcomes in mouse. World immune regulation meeting 2015, Swiss Institute of Allergy and Asthma Research (SIAF). Davos, CHE., Mar 2015, Davos, Switzerland. hal-02740428

\section{HAL Id: hal-02740428 \\ https://hal.inrae.fr/hal-02740428}

Submitted on 2 Jun 2020

HAL is a multi-disciplinary open access archive for the deposit and dissemination of scientific research documents, whether they are published or not. The documents may come from teaching and research institutions in France or abroad, or from public or private research centers.
L'archive ouverte pluridisciplinaire HAL, est destinée au dépôt et à la diffusion de documents scientifiques de niveau recherche, publiés ou non, émanant des établissements d'enseignement et de recherche français ou étrangers, des laboratoires publics ou privés. 


\section{Consecutive food and respiratory allergies amplify systemic and}

Bouchaud G., Gourbeyre P., Bihouée T., Aubert P.,

Lair D., Cheminant MA., Denery-Papini S., Neunlist M., Magnan A. and Bodinier M.

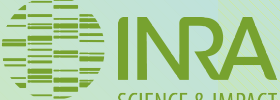

A L

INRA, UR1268 BIA, rue de la géraudière, BP 71627, F-44316 Nantes, France

INSERM, UMR1087, Institu du thorax, Nantes, F-440000, France

Background: The increase prevalence of atopic disease has become a major challenge for allergists and public health authorities. The natural history of the atopic march is still very poorly understood.

Aim: Establishment of a new mouse model combining food and respiratory allergy define a way to analyse the atopic march by investigating immunological and physiological parameters.

Methods: Mice were sensitized to wheat allergens by intraperitoneal and oral administration and then exposed to house dust mite allergens in intranasal. Allergic reaction was monitored by measuring levels of IgE and histamine. Then, immune response was evaluated by cell number and cytokine production in lymphoid organs, gastro-intestinal tract and respiratory tract. Physiological parameters were also analysed by exploring paracellular and transcellular permeability as well as airway hyper-responsiveness.

\section{Additive effect on blood marker of allergy:}
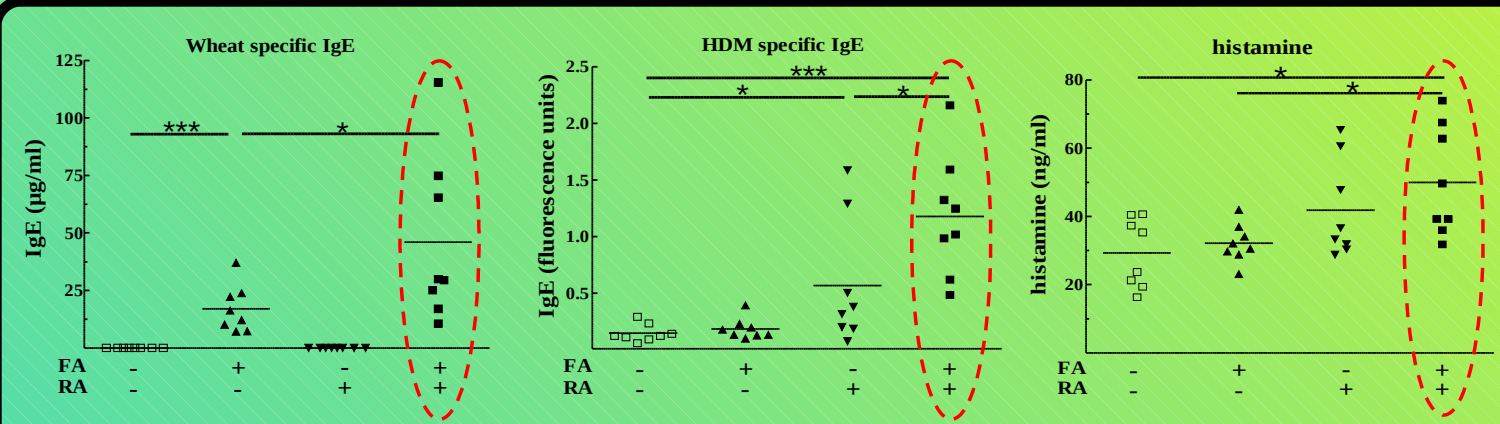

Blood samples were collected and specific IgE and histamine were

measured by ELISA

FA: Food Allergy RA: Respiratory Allergy

Mice double exposed to allergen (HDM and wheat) showed higher level of blood marker of allergy compared to single exposed mice or control revealing additive effect.

\section{Double allergy drives T-helper response in an organ specific manner:}

\section{Gastro-intestinal Tract}

Lung

Cytokine were measured by ELISA in cell culture supernatants after non specific activation from either Peyer patches (Gastrointestinal tract) and Broncho-alveolar lavages (Lung).
Th1
Th2
Th17
Treg
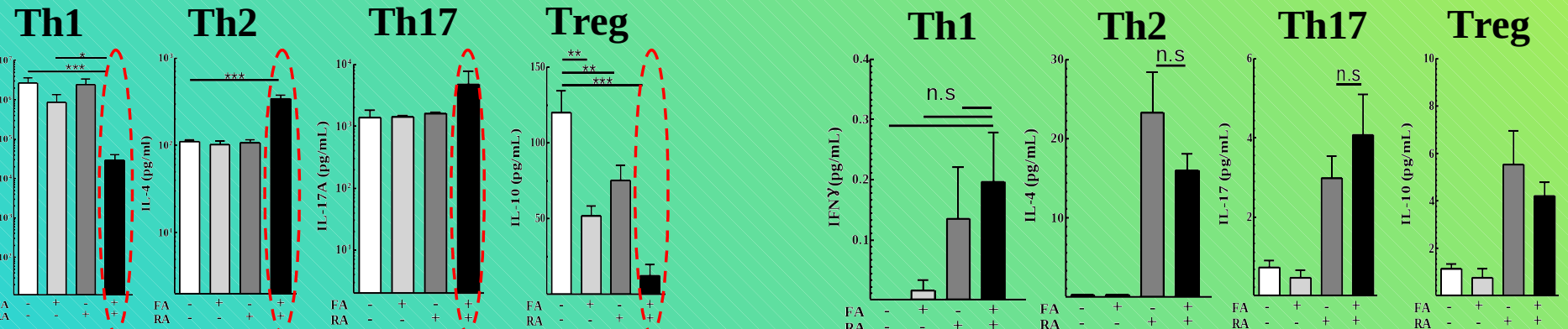

Double allergy promotes Th2 and Th17 environment together with inhibiting Th1 response and tolerance specifically in intestinal without perturbing lung.

\section{Mix allergy exacerbates intestinal symptoms but not respiratory parameters:}

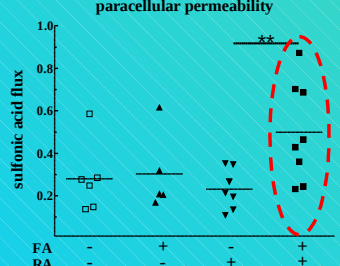

Alteration of intestinal physiology in mice exposed to both allergy.

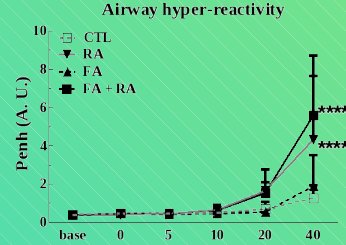

Metacholine $(\mathrm{mg} / \mathrm{mL})$

Combined allergies do not influence lung function 